\title{
Marginally speaking
}

\author{
Tommaso M. Milani \\ University of the Witwatersrand, South Africa
}

tommaso.milani@wits.ac.za

\begin{abstract}
This article engages with the semantic ambiguity of the notion of the 'margins', together with its heuristic potential. It begins by discussing how the margins can be strategically employed as unsettling vantage points through which to re-read existing sociolinguistic research on 'non-normative' linguistic practices in Sweden. Moreover, on the basis of data on same-sex desire in South Africa, the article shows how adopting a perspective 'from the margins' runs on a razor-thin edge between reason and irrationality, intelligibility and absurdity, shedding light on the limits of sociolinguistics and (critical) discourse analysis.
\end{abstract}

Keywords: margins, Rinkeby Swedish, linguistic hybridity, same-sex desire, nonnormative linguistic practices.

\section{LOCATIONS, POSITIONS AND OTHER SITES OF ENUNCIATION}

Over the last two years, the expression 'theory from the South' has started to echo increasingly more often and more loudly in a variety of intellectual spaces, from anthropology to urban studies, from politics to sociolinguistics, at least in the academic circles of post-colonial, post-apartheid South Africa in which I move. I give two examples. At a symposium on 'Language Practices, Migration and Labour' organised at the University of the Western Cape in October 2012, several South Africa-based scholars raised numerous reservations about the applicability and relevance of the notion of 'superdiversity' (Vertovec 2007) to the multilingual and multisemiotic conditions in contemporary South Africa. By the same token, the question of how cities 'from the South' should be theorised from a non-Western perspective loomed large at an inter-disciplinary workshop on urban spaces held at the University of the Witwatersrand, Johannesburg in April 2013. These are not two isolated events that I strategically deploy to set up the scene for this article. Rather, they are historical materialisations of more long-standing discursive formations that have revolved around the question of developing theoretical tools through which to capture phenomena 
in post-colonial conditions. It is perhaps unsurprising that such discussions have received renewed impetus as a result of, and in response to, the relatively recent publication of Raewyn Connell's (2007) Southern Theory as well as Jean and John Comaroff's (2012) Theory from the South.

Apparently unaware of each other's work (Comaroff and Comaroff 2012), these three authors reach very similar conclusions, albeit considering very different contexts. Connell points to the universalising tendencies of 'Western theory', that is, the attempt to present as universal what is in actual fact a theoretical leap made on the basis of very local - European or North American - data. As Edensor and Jayne (2012: 8) have correctly noted, Connell does not ask for a complete rejection of 'Western' theoretical concepts, but rather argues for transcending North/South and East/West binaries through the creation of 'dirty theory', a hybrid and messy conceptual entanglement 'which chooses ideas that suit particular situations' (Edensor and Jayne 2012: 8; see also Wodak (2001) for a similar proposal based on Mouzelis's (1995) notion of 'conceptual pragmatism').

Reasoning along similar lines, the Comaroffs underscore the Eurocentric bias of much contemporary scholarship in the social sciences and the humanities, an academic enterprise in which the North is consistently and unashamedly posited as 'the wellspring of universal learning' and the South as 'a place of parochial wisdom, of antiquarian traditions, of exotic ways and means. And above all, of unprocessed data' (Comaroff and Comaroff 2012: 1). In their view, we should look instead at the global South as a site which 'affords privileged insight into the workings of the world at large' (2012: 47), thus ultimately leading us to exceed the very North/South dichotomy.
The reading of both books raises more questions than it provides answers: What counts as the 'South', or the 'West' and the 'North', for that matter? Is the South a geographical location or a sociopolitical position? Do Australia and New Zealand count as the South in the same way as, say, Brazil or South Africa do? Do former 'Eastern bloc' countries form part of the South by virtue of their socio-political, post-Soviet conditions? Why invoke one pole of a binary - South - if the ultimate goal is to outstrip such dichotomy? And, for the purpose of this journal, what would it entail to theorise a sociolinguistics from the South?

The main problem is that the very act of using a particular spatial and/ or sociocultural, political or historical position - South - brings with it the dreaded spectre of essentialism, namely the assumption that conditions in the South are inherently and ontologically different from those in the North, or that data generated in Southern contexts necessarily need to be read through nonNorthern theoretical heuristic lenses. Of course, as post-structuralism has taught us, dyadic thinking is intrinsically reductionist for several reason. It is bound up with processes of epistemological power whereby one element of the binary is recast as better, more suitable, or academically 'cooler' than the other (see also Baker 2008). Moreover, post-colonial scholars have pointed out that binary understandings fail to account for the interconnectedness of the elements of a dyad. For example, it would be simplistic to view the colonies as geographically far-away spaces external to the metropole. Quite the contrary, colonies and metropoles were mutually constitutive, creating complex forms of social, cultural, economic and epistemological interdependencies (see Said 1980). Finally, dyadic thinking runs the risk of creating 
allochronic histories. Most cogently expressed through Johannes Fabian's (1983) notion of 'denial of coevalness', the point here is that, whether posited as backwards and not-there-yet or as ahead of time and 'harbingers of future history' (Comaroff and Comaroff 2012: 12), post-colonial contexts of the South are inevitably presented as belonging to a different temporal dimension from their Northern counterparts.

It is because of these limitations that, in line with the rationale underlying the creation of this journal, I would argue for a different type of positionality, one that is more multifaceted, more ambiguous, and more uncomfortable than the South espoused by Connell and the Comaroffs, namely that of the margins. This is because what is 'marginal' points us towards what is non-central, non-dominant, and non-hegemonic. However, such lack of centrality is never stable. This is insofar as what counts as 'marginal' can never be fully pinned down; it is in constant flux and is the object of continual negotiations. Moreover, being the fringes or borders of something, the margins have the potential to highlight the limits of the knowable.

Needless to say, in arguing for margins as a theoretical standpoint, I am not envisaging an all-encompassing explanatory apparatus with predictive potential. Rather, I see margins as a heuristic lens through which to interrogate the production of knowledge about particular socio-linguistic arrangements.

It is precisely the ambiguous semantics of the margins, together with its explanatory potential, that will be explored in more detail in the remainder of this article. I will begin by discussing how the margins can be strategically employed as a 'queer,' unsettling vantage point on the edges of an epistemological abyss, a location from which to pause and do some airing, casting a critical gaze both inwards towards the margins themselves and outwards towards the centres. I will then move on to show how adopting a perspective 'from the margins' runs on a razor-thin edge between reason and irrationality, intelligibility and absurdity, shedding light on the limits of sociolinguistics and (critical) discourse analysis. In pursuing this risky enterprise, I will be referring to my own and others' work on 'non-normative' linguistic practices in Sweden as well as on language and same-sex desire in South Africa.

\section{MARGINS - \\ UNCOMFORTABLE SITES FOR SELF-REFLECTION}

Qver the last thirty years or so, sociolinguistic research has drawn attention to the emergence of what came to be described as 'new' linguistic phenomena developing in the multilingual and multicultural peripheries of European urban environments. Straattaal in the Netherlands, Kanaaksprach in Germany, and rinkebysvenska (Rinkeby Swedish) ${ }^{1}$ in Sweden gained considerable attention from the media and academics alike. Analogous to its European cousins, rinkebysuenska soon became something of a Foucauldian conundrum: a problem to be scrutinised, a category to be defined, and a disorder to be regulated.

Earlier studies about Rinkeby Swedish aimed at outlining the phonological, morphological and syntactic characteristics of this 'new' phenomenon, with a view to determining whether it was a language 'variety' in its own right (see e.g. Kotsinas 2001). Conversely, more recent work is founded upon a post-structuralist epistemology that treats language not as a pre-existing entity but as an emergent property of interaction. Focusing on linguistic practices, 
such studies offer painstakingly detailed examples of verbal exchanges, in which speakers creatively deploy linguistic resources in order to negotiate a variety of different and often conflicting identities. For example, Haglund's (2005) ethnographic study in a Swedish school illustrates how adolescents are aware of the higher value of standard Swedish versus multilingualism in Swedish society, something that is also reflected among their teachers. However, these adolescents do not passively accept this linguistic hierarchy but also contest it in daily interactions. As Haglund puts it, the contestation takes the form of 'objections to the emphasis on monolingualism, attempts at claiming the status of multilingualism and varieties of Swedish that are not considered "pure"' (2005: 113).

By the same token, Jonsson and Milani's (2012) ethnographic study of another Swedish educational context illustrates how, in the school in question, speaking 'standard Swedish' is an index of being a good student, whereas 'youth language' is synonymous with unruly behavior. And, whilst pupils often subscribe to this dichotomy, use of standard Swedish is not always serious but may be parodic in daily interactions. This leads the authors to conclude that the adolescents in the study are staging a Bakhtinian carnival that is 'both critical of social order and complicit with it' (Wolfreys 2004: 27). On the one hand, these adolescents skilfully mobilise the dichotomy between standard Swedish and youth language, together with the associations related to them. The parodic keying of the interaction subtly disturbs this order, however, not least because parody is never sheer imitation of an original but 'simultaneously change[s] the original through recontextualization' (Pennycook 2007: 587).
Jonsson's (2007) doctoral dissertation also shows how sexist and homophobic language has a specific local meaning in the school under investigation. Without downplaying the negative effects of these linguistic exchanges in terms of female and homosexual oppression, Jonsson illustrates how ethnic insults, homophobic and misogynist language are important resources through which male adolescents can compete against each other and negotiate a 'local masculine order' (Evaldsson 2005: 764) in which power, authority and solidarity are enacted and/or contested (see also Milani and Jonsson 2011).

Indeed, these studies are wellmeant attempts to counter wide-spread societal perceptions that paint linguistic practices in Swedish suburbs with highly dark hues as inherently 'non-Swedish' phenomena, the causes of social trouble and educational under-achievement, as well as the outer manifestations of young men's 'inner' sexist and homophobic tendencies. These studies are also genuine academic efforts to question a conception of languages as monolithic bounded entities that can be easily demarcated. Whether researchers - including myself - succeeded in it is more debatable. In what follows, I will not consider the full range of academic work on Rinkeby Swedish, but will cast a fairly narrow selfreflexive look on my own involvement in the production of knowledge about this linguistic phenomenon.

When I first started working on representations of Rinkeby Swedish in the media (Milani 2010) and then moved on to analyse linguistic practices in Swedish schools together with Rickard Jonsson (Milani and Jonsson 2011, 2012), I was moved by a critical discourse analytical thrust to 'do good', to show the complexity of the life of language in daily interaction, something that was consistently 
erased in the debates taking place in the Swedish media. Good intentions aside, Rickard and I might nonetheless have been complicit in reinforcing a view of Rinkeby Swedish as an 'exotic' 'aberrance'. We might have turned Rinkeby Swedish into a 'margin' in the Swedish sociolinguistic soundscape. This is mostly the result of two interrelated factors: 1) the choice of speakers on whom we focused; and 2) the vocabulary that we employed to describe the interactions among those speakers.

To begin, our analyses are based nearly exclusively on those adolescents that have been singled out by the media or their peers as 'immigrant guys' (invandrarkillar), despite the fact that the greatest majority of them was actually born and raised in Sweden. One could argue that such choice was ethnographically motivated. It stemmed from the researcher's (Rickard) insights into the school in which he spent several months observing everyday life there. Rickard was moved in the direction of a particular group of male pupils because they were constantly talked about with mixed feelings by teachers and peers; they were at the same time 'feared' and 'hated', 'desired' and 'despised'. It is their position as 'Other' that justified the researcher choosing them as object/subject of sociolinguistic investigation. But that very choice was not unproblematic. Why not consider those adolescents who are perceived as 'ethnically Swedish' but nonetheless employ Rinkeby Swedish in the school? These are the 'wannabes', as they are called by the 'immigrant guys'. Empirically, the answer is simple. In the school studied by Jonsson, the 'wannabes' were less interesting; they were never at the centre of attention; their interactions both with their peers and the researcher were more 'banal', less dramatic than the highly stylised performances (Coupland
2007) of the 'immigrant boys', who were constantly playing with language and ethnic boundaries, at the same time reproducing and contesting such divisions. However, by failing to fully investigate the 'wannabes', we might have contributed to reproducing a link between Rinkeby Swedish and non-Swedishness.

Put differently, Rickard and I put the spotlight on the 'immigrant guys'; we wanted to put them at the centre of academic attention with a view to telling a different story, a more complex and nuanced narrative of these adolescents, their lives, and their aspirations, showing why they employed certain linguistic strategies in order to accomplish particular identity purposes. Yet, the very act of singling them out might have backfired, re-inscribing their 'marginal' Otherness. Such process of academic othering was most likely reinforced through the vocabulary we employed, a set of metalinguistic labels influenced by post-colonial theories of hybridity and third space. To take an example, we argued that it is a

duality of positions that constitutes the shared experience among many adolescents in the schools under investigation. It is perhaps the most tangible manifestation of what Homi Bhabha calls 'the third space': a locus where static forms of affiliation are no longer tenable. These adolescents are neither 'foreign' to Sweden [...] nor 'indigenous'. Instead they find themselves caught up in the very interstices between these two opposite positions, juggling creatively with available linguistic resources in order to express this experience of 'in-betweeness'. (Milani and Jonsson 2012: 59)

Also following Bhabha, we described this 'creative juggling' in terms of linguistic hybridity. Our intentions were indeed celebratory; but 'the 
celebration of happy hybridity', as Otsuji and Pennycook (2010: 244) call it, is not entirely innocuous. As Bailey notes, hybridity is only meaningful against a backdrop of essentialism that analysts claim to have rejected' (2007: 207). This is because, it 'carries with it connotations of pure and coherent anterior systems', from which it is supposed to stem. From this, it follows that 'hybridity' .... pays lip service to certain types of social difference, while implicitly reinforcing the political and economic boundaries that constitute those groups as different and unequal' (2007: 207).

This is not to say that an analysis informed by 'linguistic hybridity' should be discarded completely. Rather, I would like to propose that linguistic hybridity is an important concept as long as it is specified that there is no anterior purity from which it originates. Or to put it differently, linguistic hybridity is not the debris formed from the crossfertilisation of 'pure' elements. As long as it is not essentialised as the 'dirty' trait of the 'margins', linguistic hybridity can be a powerful concept through which to dislocate the alleged homogeneity and purity of the 'centre', namely standard languages. A radical view from the margin then should highlight that Rinkeby Swedish reminds us that all languages are ultimately 'pidgins', 'creoles' or 'hybrids' (see also Mufwene 2001). What appears to be an 'exceptional' case of language practice actually makes palpable the often forgotten nature of all languages (see also Makoni and Pennycook 2007).

\section{ON THE FRINGES OF THE SAYABLE}

7 he reflections in the previous section moment of personal academic crisis.
What I am actually arguing is to put oneself at the margins of one's own knowledge production and question oneself vis-à-vis the object/subject of study. It might also seem that I am striving towards a relativist form of thinking that ultimately leads to the impossibility of any certainty, and ultimately leads to an epistemological impasse. Rather than seeing it in terms of 'impossibility', what I want to do here is to deploy a position from the 'fringes' in a more productive way as a standpoint from which to interrogate the limits of what can be said through the tools of sociolinguistics and discourse analysis.

I encountered such an epistemological margin whilst conducting research on same-sex desire in the South African context. The project started as a fairly ordinary audience reception study in which I interviewed 15 white, middle-class South African men who desire other men, asking them to comment on a series of online profiles containing some controversial information about racial, gender preferences (e.g. 'whites only', 'no fats, no fems', 'only straight-acting guys'). As often is the case during deep interviews, the men in the project recounted long personal stories when commenting on the online profiles. What was most unexpected is that four of them mentioned at some point that they had either been sexually harassed or had been raped by another man. Of course, the acknowledgment of sexual violence is not particularly new in research on language, gender and sexuality. But male rape seldom figures in South African media, perhaps because only $2.6 \%$ of the reported cases of rape are perpetrated by men against other men. Whether unpredictable or not, it is interesting to highlight what Dawid ${ }^{2}$, one of the interviewees, said in relation to sexual violence. He clearly stated that 
'language is not enough' to capture what he felt when he was raped, and went on to describe how art, instead, proved to be a much more apt semiotic resource through which to express his experience of rape (see extract below).

Painting. I was very fond of painting, that's why when you asked 'What image?' burning at the stake because an image that kept on reverberating with me in many of my works was a man being burnt at the stake or people being thrown into the fire. Even simple works such as... I did a series of paintings on the crucifixion and yet there is always fire around the crucif... so, you know, it was more the burning at the stake image than the crucifixion thing. I think because I really got into painting I used I used my cum in painting. I would cut myself and bleed into my paint and use that as so there was there was an ability to take what was physically what was the body and actually inject that into what I was producing artistically as well.

I intend to analyse this extract at length elsewhere, but what I need to highlight here is the unsettling character of Dawid's story. The most disconcerting part lies in the fact that Dawid provided me with empirical evidence of the limits of what can be analysed by just looking at discourse, or better, at the entextualisation of an experience of violence. One might argue that this is nothing particularly new. To employ Friedrich Nietzsche's (1995 [1927]) terminology, language belongs to the domain of the Apollonean, a realm in which order has been put; it is the sublimation of life. Violence, on the contrary, belongs to the Dionysian, which is the chaotic world of the Bacchae, the frantic women in Euripides' tragedy who shred a herd of cattle with their hands. Hence, messier, 'dirtier', visual art may be better suited than language to capturing the non-sublimated, corporeal aspect of life.

Dawid's story is also disturbing because it strikes a more personal chord. It is a powerful reminder of an evening which started as a fun Saturday night with colleagues and friends after a conference in a foreign country, a night which could have ended terribly but did not. The story reverberates with the feelings of a linguist in his late 30 s being held down by his wrists by a younger man. It is the inability to scream, the sense of powerlessness when someone is trying to impose his will and potentially violate your body. But, in my own experience, language, visual means or any form of signification cannot and will never fully encapsulate that moment. It is a visceral feeling in the bowls, a nausea that cannot be represented, but can only be experienced; it cannot be told but can only be felt.

It is interesting that, whilst psychoanalysts openly recognise the inadequacy of verbal and written language in expressing traumatic experiences (see e.g. Hook 2003), sociolinguists - even liberal, post-structuralist ones - seem to be less keen to acknowledge such limitation (see, however, Harvey and Shalom 1997; Cameron and Kulick 2003; Busch 2012). In a variety of academic forums, the point that language is never 'enough' was explained away with the argument that Dawid and I have not yet worked through our trauma. But let us assume for a moment that we actually had. Let us suppose instead that the very act of positioning us as 'not there yet' is a patronising discursive act through which disciplinary power is (re)enacted. What Dawid and I did is point a finger towards the margins of language/discourse. By provocatively questioning the very centre on which a whole discipline is built, we came to inhabit a 'marginal 
position,' namely the standpoint of the Shakespearian fool that constantly runs the risk of becoming incomprehensible

In broad terms, marginally speaking means that one should never be afraid of acknowledging the limit of one's own knowledge production. It also entails not fearing the epistemological abyss that lurks at the fringes of one's own site of enunciation (Menezes de Souza 2007). A view from the margins should instead highlight the limits of the discipline from which one is speaking, perhaps with a view to overcoming them with the help of more promiscuous methodologies, or maybe acknowledging such curbs modestly.

\section{ENDNOTES}

${ }^{1}$ Rinkeby is the name of a neighbourhood of Stockholm where this linguistic practice allegedly originated. In Swedish media and popular discourse Rinkeby has become the icon of 'immigrantness' and social problems.

${ }^{2}$ Dawid is a pseudonym.

\section{REFERENGES}

Bhabha, Homi. 1994. The Location of Culture. London: Routledge.

Baker, Paul. 2008. Sexed Texts: Language, Gender and Sexuality. London: Equinox.

Bailey, Benjamin. 2007. Heteroglossia and boundaries. In Monica Heller (ed.). Bilingualism: A Social Approach. Basingstoke: Palgrave Macmillan. 257-274.

Busch, Brigitta. 2012. The linguistic repertoire revisited. Applied Linguistics 33 (5): 503-523.

Cameron, Deborah and Don Kulick. 2003. Language and Sexuality. Cambridge: Cambridge University Press.

Comaroff, Jean and John L. Comaroff. 2012. Theory from the South: Or, how Euro-America is Evolving toward Africa. Boulder, CO: Paradigm Press.

Connell, Raewyn. 2007. Southern Theory: The Global Dynamics of Knowledge in Social Science. Cambridge: Polity Press.

Coupland, Nikolas. 2007. Style: Language, Variation and Identity. Cambridge: Cambridge University Press.

Edensor, Tim and Mark Jayne. 2012. Introduction: Urban theory beyond the West. In Urban Theory Beyond the West: A World of Cities. In Tim Edensor and Mark Jayne (eds). London: Routledge.1-28.

Evaldsson, Ann-Carita. 2005. Staging insults and mobilising categorisations in a multiethnic peer group. Discourse $\mathcal{E}^{\circ}$ Society 16 (6): 763-786.

Haglund, Charlotte. 2005. Social interaction and identification among adolescents in multilingual suburban Sweden: A study of institutional order and sociocultural change. Unpublished PhD dissertation. Stockholm: Stockholm University.

Harvey, Keith and Celia Shalom. 1997. Language and Desire: Encoding Sex, Romance and Intimacy. London: Routledge.

Hook, Derek. 2003. Language and the flesh: Psychoanalysis and the limits of discourse. Pretexts: Literary and Cultural Studies 12 (1): 43-64.

Jonsson, Rickard. 2007. Blatte betyder kompis: Om maskulinitet och språk i en högstadieskola. Stockholm: Ordfront.

Kotsinas, Ulla-Britt. 2001. Pidginization, creolization and creoloids in Stockholm. In Norval Smith and Tonjes Veenstra (eds). Creolization and Contact. Amsterdam: John Benjamins. 125-156.

Makoni, Sinfree and Alistair Pennycook. 2007. Disinventing and reconstituting languages. In Sinfree Makoni and Alistair Pennycook (ed). Disinventing and Reconstituting Languages. Clevedon, UK: Multilingual Matters. 1-41.

Menezes de Souza and Lynn Mario T. de Souza. 2007. Entering a culture quietly: Writing and cultural survival in indigenous education in Brazil. In Sinfree Makoni and Alistair Pennycook (eds). Disinventing and Reconstituting Languages. 
Clevedon, UK: Multilingual Matters. 135-169.

Milani Tommaso M. 2010. What's in a name? Language ideology and social differentiation in a Swedish print-mediated debate. Journal of Sociolinguistics 14 (1): 116-142.

Milani, Tommaso M. and Rickard Jonsson. 2011. Incomprehensible language? Language, ethnicity and heterosexual masculinity in a Swedish school. Gender E Language 5 (2): 241-269.

Milani, Tommaso M. and Rickard Jonsson. 2012. Who's afraid of Rinkeby Swedish? Stylization, complicity, resistance. Journal of Linguistic Anthropology 22 (1): 44-63.

Mouzelis, Nikos. 1995. Sociological Theory: What Went Wrong? Diagnoses and Remedies. London: Routledge.
Mufwene, Salikoko. 2001. The Ecology of Language Evolution. Cambridge: Cambridge University Press.

Nietzsche, Friedrich. 1995. The Birth of Tragedy. Mineola, NY: Dover Thrift.

Otsuji, Amy and Alistair Pennycook. 2010. Metrolingualism: Fixity, fluidity and language in flux. International Journal of Multilingualism 7 (3): 240-254.

Vertovec, Steven. 2007. Super-diversity and its implications. Ethnic and Racial Studies 30(6): 1024-1054.

Wodak, Ruth. 2001. The discourse-historical approach. In Ruth Wodak and Michael Meyer (eds). Methods of Critical Discourse Analysis. London: Sage. 63-94.

Wolfreys, Julian. 2004. Critical Keywords in Literary and Cultural Theory. Basingstoke: Palgrave Macmillan. 